\title{
Albanian Turnover: Is the Job Embeddedness Construct Predictive in an Albanian Context?
}

\author{
Wendy S. Harman \\ St. George's University \\ Michael Blum \\ Julia Stefani \\ Ada Taho \\ Truman State University
}

\begin{abstract}
This paper seeks to expand the knowledge of the influence of job embeddedness using a sample of Albanian employees working in the banking industry. Findings from the Albanian sample differed from previous findings in embeddedness research conducted in the US. The influence that the affective components of turnover, that of commitment and satisfaction, have on intent to leave as well as the highly predictive (in U.S. samples) job embeddedness construct influenced turnover in this sample of Albanian bank employees. Demographic and cultural explanations for these findings suggest that job embeddedness may have differential effects cross-culturally.
\end{abstract}

\section{Background}

March and Simon (1958: 48) stated in their classic book, Organizations, "Few aspects of organizational behavior have been subject to so much speculation as have morale, productivity and turnover." Within the domain of organizational behavior, turnover and employee retention remains an active area of theory and empirical research. This paper seeks to extend the literature on turnover, and more specifically, on job embeddedness, to include cross-cultural comparisons between findings from the U.S. and replication data collected from Albania. The paper will first present a short review of the literature on turnover and embeddedness most pertinent to the current discussion. Second, the authors will present formal hypotheses and the study and findings, and conclude with remarks regarding the future of the study of cross-cultural turnover and employee retention.

\section{Turnover}

March and Simon's (1958) seminal book signaled the beginning of the development of turnover theory. According to their theory, members participate in the organization as long as inducements, such as pay, match or exceed the employees' inputs. The interaction of the inputs and inducements are influenced by two motivational components: the perceived desirability of leaving and the ease of leaving. Being satisfied in one's job reduces the perceived desirability of leaving. Ease of leaving is influenced by the external economy, though March and Simon suggested that issues such as the visibility of the individual employee (other firms see and want to hire the person), the number of firms visible (the perception of jobs being plentiful leads to a 
higher perceived ease of movement), the current organization's prestige (easier to move from a well known company than a little known company), and the individual's propensity to search for a job all influence ease of movement.

Porter and Steers (1973) suggested that the issue of met expectations was central to the individual's decision to leave an organization. Each employee has his or her own set of expectations upon entering an organization. Should these expectations not be met, the individual will become dissatisfied and leave. Mobley (1977) suggested that a negative evaluation of the present job leads to job dissatisfaction, thoughts of quitting, and an evaluation of job seeking expected utility and cost of quitting. Should the expected utility be high and the cost of quitting low, the individual will then intend to seek alternatives followed by an actual search for alternatives. Should alternatives be found, the individual will then evaluate those alternatives against one another and the current job. The employee then engages in quit decisions and actual turnover. Again, as with the previous theories of turnover, tests of the model either in part or as originally theorized, produced mixed findings.

Hom, Griffeth and Sellaro (1984) and Hom and Griffeth (1991) suggested that job dissatisfaction leads to withdrawal cognitions and a consideration of the expected utility of leaving. The expected utility of leaving, should it be high, leads to a job search, comparison of alternatives and turnover. The withdrawal cognitions, however, may lead to turnover without search if the individual expects to be able to find other employment or decides to pursue other, non-work alternatives.

Following a comprehensive review of the literature on turnover, Price (1977) suggested a wide-ranging turnover model. Price suggested that several job attributes influence job satisfaction. Job satisfaction, then, influences turnover. The availability of alternatives moderates the relationship between job satisfaction and turnover. Price and Mueller (1981; Curry, Wakefield, Price, \& Mueller, 1986) expanded on the model. They included more influences on job satisfaction, which then would influence organizational commitment. Issues such as professionalism, general training, kinship responsibility, and company and work-unit size could also directly influence organizational commitment. Organizational commitment, then, was proposed to lead to the intent to leave (influenced by opportunity) and turnover (also influenced by opportunity).

The Expanded Model of Turnover (Mobley, Griffeth, Hand and Meglino, 1979) included job-related perceptions, individual values, and labor-market perceptions as influences on job satisfaction and expected utility of both the present job and the alternatives. The authors suggested that these three components lead to search and intent to quit. The intention to quit is the direct precursor to turnover. They also suggested that, should the individual not be able to gain alternative employment, the employee would be more likely to engage in withdrawal behaviors such as absenteeism.

In the intervening years, researchers developed more models, and they include some discussion of the influence of the same mediating variables: job satisfaction, organizational commitment, and job alternatives (e.g., Farell \& Rusbult, 1981; Steers \& 
Mowday, 1981; Sheridan \& Abelson, 1983; Hulin, Roznowski \& Hachiya, 1985; Lee \& Mitchell, 1994). These mediating variables are consistently responsible for predicting the majority of the explained variance in turnover at the individual level (e.g., Jaros, 1997 in Mitchell, Holtom, Lee, Sablynski \& Erez, 2001). Job satisfaction is an affective reaction to specific components of a person's job, as well as an evaluation of the job overall, (Spector, 1997). Job satisfaction is negatively associated with voluntary turnover (e.g. Mobley, 1977; Spector, 1997). Organizational commitment is typically defined as an affective psychological state that links employees to their organizations (Meyer \& Allen, 1988), and is negatively related to turnover (Bluedorn, 1982; Griffeth et al., 2000; Mathieu \& Zajac, 1990). This suggests that negative attitudes such as low job satisfaction and low organizational commitment are predictive of higher rates of turnover. Additionally, other variables such as job search behaviors (Blau, 1993) and the perception of job alternatives (Gerhart, 1990) have been found to be predictive of employee voluntary turnover. When considering attitudes and unemployment, Carsten and Spector (1987) found that when unemployment rates were high, attitudes had less influence on turnover decisions than when jobs were plentiful. Thus, the major theories of turnover combine both attitudinal measures such as job satisfaction and commitment and the "ease of movement" measures such as job alternatives and job search behavior (Mitchell, et al., 2001). While research has found these predictor variables to be significant, Griffeth, Hom, and Gaertner (2000) found the variance explained by the attitudinal variables to be only around $5 \%$. Perceptions of job availability and intent to search accounted for even less variance in actual turnover (Griffeth, Hom, \& Gaertner, 2000; Steel \& Griffeth, 1989).

\section{Albania}

Albania is located in Eastern Europe, between Greece and Macedonia and the Mediterranean Sea. Albania has 3.6 million inhabitants and is one of the poorest countries in Europe with an unemployment rate of $13.8 \%$ and poverty rate of $18.5 \%$. The per capita income in 2007 was in U. S. dollars, \$3,150.00. The GDP for 2006, according to the World Bank (2008) was $\$ 9.1$ billion in U. S. dollars with $5 \%$ GDP growth. The majority of employment is in the agricultural sector $(60 \%)$ and then in the service sector $(39 \%)$, which is where the sample for this study was drawn. The capital city is Tirana with an estimated 600,000 people (U.S. Department of State, 2007). According to the 2001 census data analyzed by INSTAT (The Institute of Statistics of Albania, 2004), Albania is experiencing major migration from rural to urban areas. The typical internal migrant is young (under 40 years of age) and possesses significant human capital as he or she has high skill sets and/or posseses an undergraduate degree. Albanians are looking for a satisfying work environment, and according to the two Albanian nationals who are co-authors on this paper, Albanians are aware of their human capital. Albanians view the United States positively, and younger Albanians desire to have lives similar to those of their contemporaries in the U. S. One way to achieve this is by working in the banking industry. The banking industry is viewed as one of the best industries to in which to work in Albania. Taking this discussion as predictive of Albanian turnover, we suggested the following hypotheses: 
Hypothesis 1: High levels of job satisfaction will be related to lower intent to leave.

Hypothesis 2: High levels of organizational commitment will be related to lower intent to leave.

Hypothesis 3: Perceived job alternatives will be related to higher intent to leave.

Hypothesis 4: Job search behaviors will be related to higher intent to leave.

\section{Embeddedness}

The most recent and influential developments in the study of voluntary turnover include the addition of Mitchell and colleagues' (2001) theory of job embeddedness, which focuses rather on why people stay than why they leave. Traditional turnover models suggest that employees leave because of negative job attitudes, and have assumed that staying is simply the inverse of leaving.

Mitchell et al. (2001) proposed the job embeddedness construct to explain why employees remain in an organization based on a number of influences rather than solely on positive job attitudes. Job embeddedness suggests that people remain in organizations based on three criteria which are influenced by elements both on the job and in the community: 1 . The extent to which they are linked to other people and activities, 2. The extent to which they feel they fit in their organizations and communities, and 3 . What they would have to sacrifice if they left. Links are connections that a person has with other individuals and institutions. The more connected an individual and/or his or her family is with the organization and the community, the more difficult leaving is and the more embedded the person is. Fit is the individual's perceived compatibility with the organization and with the community. The employee's personal values and career goals need to be in line with the overall organizational culture, allowing the employee to feel connected to the organization. Additionally, the individual needs to feel a fit between his or her family and the local community. Sacrifice refers to the perceived costs associated with leaving. These costs may be physical or psychological. Leaving may mean giving up the advantages associated with tenure in the organization (pay, corner office), as well as the personal losses such as close friendships with coworkers or benefits unique to the organization. Community sacrifices are applicable only if the person will move to a new location. For example, the loss of the feeling of belonging to a community, the loss of favored local restaurants, and selling the home the person's children were raised in could influence the community sacrifice dimension.

The embeddedness construct has consistently predicted employee retention (lack of turnover) over and above the traditional constructs of job satisfaction and organizational commitment. Simply put, those who are embedded are less likely to leave (Mitchell et al., 2001; Lee, Mitchell, Sablynski, Burton \& Holtom, 2004). Following the findings of 
the U.S.-based research on job embeddedness, we suggested the following hypotheses:

Hypothesis 5: Job embeddedness is negatively related to intent to leave over and above that accounted for by job satisfaction and organizational commitment.

Hypothesis 6: Job embeddedness is negatively related to intent to leave over and above that accounted for by job search and perceived job alternatives.

In the major cities in Albania, the unemployment rate for migrants is much higher (31\%) than the country average and is higher than that of the region they left $(21-22 \%$;

INSTAT, 2004). Given the high levels of unemployment in the country and for migrant workers, we suggested the following hypothesis:

Hypothesis 7: Perception of job alternatives will predict intention to leave over and above that accounted for by job satisfaction and job embeddedness.

\section{Methods}

\section{$\underline{\text { Sample }}$}

The sample was drawn from three banks operating in Tirana, the capital city of Albania. Two of the researchers are Albanian nationals studying business in the U.S. They gained access to the banks through personal contacts in early 2007. Data were collected during the summer of 2007 while they were visiting home over summer break. The survey was written in English and translated by the two researchers into Albanian. The survey was drawn from Lee et al., (2004) as these authors developed their survey for the banking industry in the U.S. A total of 164 surveys were distributed, and 159 were returned, for a response rate of $(97 \%)$. Within our sample $62 \%$ were women, the average age of respondents was 30 years (s.d. $=7.26), 51 \%$ were married, and the majority $(74 \%)$ had a bachelor's degree. The respondents had worked in their current positions an average three and a half years (s.d. $=4.49$ ), had been with the same organization an average of three years (s.d. $=3.70$ ), and had been in the banking industry an average of four and three quarter years (s.d., = 4.88). The high response rate was potentially influenced by the distribution of paper surveys that were completed with the researcher on site and hand collected by the researcher upon completion.

\section{$\underline{\text { Measures }}$}

\section{Demographic characteristics}

We measured age, gender, marital status, and tenure in job, the organization and industry. 


\section{$\underline{\text { Job satisfaction }}$}

We used a shortened version of Spector's (1997) Job Satisfaction Survey. To assess overall job satisfaction, we aggregated $(\alpha=.85)$ across the following six items: "All in all, I am satisfied with my job." "In general, I don't like my job," (reverse scored). "In general, I like working here." "My values are compatible with those of this organization." And "If I stay with this organization, I will be able to achieve most of my goals." Items were measured with a Likert-type, 5-point scale.

\section{Organizational Commitment}

To assess overall commitment to the organization, we used a modified 14-item version of Meyer and Allen's (1988) measure of affective commitment $(\alpha=.83)$. Items were measured with a Likert-type, 5-point scale. For example, "I enjoy discussing my organization with people outside of it." "I would be very happy to spend the rest of my career with this organization." "I do not feel like 'part of the family' at my organization."

\section{$\underline{\text { Job alternatives }}$}

Two items from Mitchell et al., (2001) were aggregated to show an overall perception of job alternatives ( $\alpha$ ? 90? What is the probability that you can find an acceptable alternative to your job?" "If you search for an alternative job within a year, what are the chances you can find an acceptable job?" Items were measured with a Likert-type, 5point scale.

\section{Job search behavior index}

We used modified version of Kopelman, Rovenpor, and Milsap's (1992) scale to measure search activity. The items were in a yes/no format, and they asked questions such as: "During the past year have you revised your resume?" "During the past year have you gone on a job interview?" And "During the past year have you talked to friends or relatives about getting a new job?" The responses from the nine items were aggregated to form an overall impression of external search behavior $(\alpha=.80)$.

\section{Intention to leave}

Following Mitchell et al., (2001), we used the modified version of Hom et al. (1984). The three items included were: "Do you intend to leave the organization in the next 12 months?" "How strongly do you feel about leaving the organization within the next 12 months?" "How likely is it that you will leave the organization in the next 12 months?" The aggregate of these items was used in the analysis $(\alpha=.83)$. Items were measured with a Likert-type, 5-point scale. 


\section{$\underline{\text { Job embeddedness }}$}

The job embeddedness items were drawn from Lee et al., (2004). We used a shortened version of the off-the-job embeddedness questionnaire. The six-items used to measure off-the-job embeddedness were as follows: "I really love the place I live." "I like the family-oriented environment of my community." "The community I live in is a good match for me." "Leaving this community would be very hard." "I think of the community where I live as home." "My neighborhood is safe" $(\alpha=.68)$. We used a modified version of the on-the-job embeddedness measure. The 14 items included were as follows: "My job utilizes my skills and talents well." "I feel like I am a good match for this organization." "I feel personally valued in this organization." "I like my work schedule (e.g., flextime, shift)." "I have a lot of freedom on this job to decide how to pursue my goals." "I fit with this organization's culture." "The perks on this job are outstanding." "I feel that people at work respect me a great deal." "I would sacrifice a lot if I left this job." "I like the authority and responsibility I have at this organization." "My promotional opportunities are excellent here." "I am well compensated for my level of performance." "The benefits are good on this job." "I believe the prospects for continuing employment with this organization are excellent" $(\alpha=.84)$. The off-the-job links dimension of the embeddedness construct exhibited an excessively low reliability level $(\alpha=.43)$, though, the on-the-job links were acceptable $(\alpha=.82)$. This led us to separate the 6 dimensions of job embeddedness and use the disaggregated components in analyses in addition to the above aggregates. To assess fit organization, six items were used $(\alpha=.70)$; for sacrifice organization, eight items were used $(\alpha=.76)$; and for links organization, three items were used $(\alpha=.82)$. To assess the community, or off-the-job embeddedness dimensions, links community did not reach an acceptable reliability level, as mentioned above $(\alpha=.43)$; fit community was assessed using four items $(\alpha=.64)$; and sacrifice community also did not reach an acceptable reliability level $(\alpha=.31)$. Links community and sacrifice community were not included in subsequent analyses.

\section{Results}

Table 1 shows the means, standard deviations, and correlations for all variables in this study. As expected, job satisfaction was negatively correlated with intent to leave, and was positively correlated with organizational commitment, on-the-job embeddedness, and off-the-job embeddedness. Organizational commitment was not significantly correlated with intent to leave, but was positively correlated with job satisfaction and onand off-the-job embeddedness. Job search behavior was positively correlated with intent to leave, and negatively correlated with on-the-job embeddedness, sacrifice organization and links organization.

\section{Tests of Hypotheses}

Ordinary Least Squares Regression was used to test Hypotheses 1-4. We tested Hypotheses 5- 7 with hierarchical linear regression (see Table 2). Hypothesis 1 stated that high levels of job satisfaction would be related to lower intent to leave. This 
hypothesis was supported $(\beta=-.38, p<.001)$. In keeping with previous research, the attitudinal measure of job satisfaction predicted intent to leave, explaining $15 \%$ of the variance. Hypothesis 2 predicted that high levels of organizational commitment would be related to lower intent to leave. This hypothesis was not supported $(\beta=-.10, n . s$.). It appears that for this sample, organizational commitment was not related to intent to leave. Hypothesis 3 suggested that perceived job alternatives would be related to higher intent to leave. This hypothesis was not significant $(\beta=.09, n . s$.) suggesting that

Table 1

Means, Standard Deviations, and Correlations

\begin{tabular}{|c|c|c|c|c|c|c|c|c|c|c|c|c|}
\hline Variable & Mean & s.d. & 1 & 2 & 3 & 4 & 5 & 6 & 7 & 8 & 9 & 10 \\
\hline $\begin{array}{l}\text { 1. Intent to } \\
\text { leave }\end{array}$ & 3.43 & 1.01 & & & & & & & & & & \\
\hline $\begin{array}{l}\text { 2. Job } \\
\text { satisfaction }\end{array}$ & 2.08 & .60 & $-38^{* *}$ & & & & & & & & & \\
\hline $\begin{array}{l}3 . \\
\text { Organizational } \\
\text { commitment }\end{array}$ & 2.26 & .50 & -.10 & $.53^{\star \star}$ & & & & & & & & \\
\hline $\begin{array}{l}\text { 4. Job } \\
\text { alternatives }\end{array}$ & 3.23 & 1.27 & .09 & .07 & .16 & & & & & & & \\
\hline $\begin{array}{l}\text { 5. Job search } \\
\text { behavior }\end{array}$ & .37 & .31 & $.17^{*}$ & -.05 & .07 & .02 & & & & & & \\
\hline $\begin{array}{l}\text { 6. Job } \\
\text { embeddedness }\end{array}$ & 2.35 & .52 & $\begin{array}{l}- \\
.34^{* *}\end{array}$ & $.71^{* *}$ & $.40^{\star \star}$ & .09 & $-.15^{\star}$ & & & & & \\
\hline $\begin{array}{l}\text { 7. Community } \\
\text { embeddedness }\end{array}$ & 2.33 & .57 & -.13 & $.28^{\star *}$ & $.18^{*}$ & .12 & -.08 & $.34^{\star *}$ & & & & \\
\hline $\begin{array}{l}\text { 8. Fit to } \\
\text { organization }\end{array}$ & 2.08 & .55 & $\begin{array}{l}- \\
.20^{* *}\end{array}$ & $.60^{* *}$ & $.33^{\star *}$ & .07 & -.10 & $.87^{* *}$ & $.32^{* *}$ & & & \\
\hline $\begin{array}{l}\text { 9. Fit to } \\
\text { community }\end{array}$ & 2.20 & .60 & -.12 & $.35^{\star *}$ & $.18^{\star}$ & .09 & -.02 & $.42^{* *}$ & $.92^{* *}$ & $.43^{* *}$ & & \\
\hline $\begin{array}{l}\text { 10. Sacrifice } \\
\text { Organization }\end{array}$ & 2.54 & .59 &. & $.67^{* *}$ & $.38^{* *}$ & .10 & $-.17^{\star}$ & $.92^{* *}$ & $.30^{* *}$ & $.60^{* *}$ & $.34^{\star *}$ & \\
\hline $\begin{array}{l}\text { 11. Links } \\
\text { Organization }\end{array}$ & .00 & .82 & $-.14^{*}$ & $.24^{\star *}$ & $.19^{\star *}$ & .08 & $.36^{* *}$ & $-29^{* *}$ & $.15^{\star}$ & $.25^{\star *}$ & .13 & $.27^{\star \star}$ \\
\hline
\end{tabular}

Links organization items were standardized. $\mathrm{N}=159$. Correlations are 1-tailed.

${ }^{*} p<.05$

${ }^{* \star}$ p. $<.01$

perception of job alternatives was not related to intention to leave the organization. Hypothesis 4 stated that job search behaviors would be related to higher intent to leave. This was significant $(\beta=.17, p<.05)$; job search was significantly related to intent to leave the organization. Hypothesis 5 posited that job embeddedness was negatively related to intent to leave over and above that accounted for by job satisfaction and organizational commitment. This hypothesis was not supported ( $\beta ?-.15, n . s$.). 
Job embeddedness did not predict intention to leave over and above job satisfaction and commitment. Hypothesis 6 stated that job embeddedness was negatively related to intent to leave over and above that accounted for by the measures of job search and perceived job alternatives. This was supported $(\beta=-.33, p<.001)$. Job embeddedness did predict intention to leave over and above external "ease of movement." Hypothesis 7 suggested that the perception of job alternatives would predict intention to leave over and above that accounted for by job satisfaction and organizational commitment. This hypothesis was not supported $(\beta=.12, n . s$.).

Table 2

Hierarchical Regression Results for Hypotheses 5 - 7

\begin{tabular}{|c|c|c|c|}
\hline Variable & $\beta$ & Total $\mathrm{R}^{2}$ & $\Delta R^{2}$ \\
\hline \multicolumn{4}{|l|}{ Hypothesis 5} \\
\hline Step 1 & & & \\
\hline Job Satisfaction & -.45 & .14 & $.14^{* *}$ \\
\hline $\begin{array}{l}\text { Organizational } \\
\text { Commitment }\end{array}$ & .14 & .16 & .02 \\
\hline $\begin{array}{l}\text { Step } 2 \\
\text { Job } \\
\text { Embeddedness } \\
\text { Hypothesis } 6 \\
\text { Step } 1\end{array}$ & -.15 & .17 & .01 \\
\hline Job Alternatives & .08 & .01 & .01 \\
\hline $\begin{array}{l}\text { Job Search } \\
\text { Behavior }\end{array}$ & .17 & .04 & $.03^{*}$ \\
\hline $\begin{array}{l}\text { Step } 2 \\
\text { Job } \\
\text { Embeddedness } \\
\text { Hypothesis } 7 \\
\text { Step 1 }\end{array}$ & -.33 & .14 & $.10^{* *}$ \\
\hline Job Satisfaction & -.45 & .14 & $.14^{* *}$ \\
\hline $\begin{array}{l}\text { Organizational } \\
\text { Commitment } \\
\text { Step } 2\end{array}$ & .14 & .16 & .02 \\
\hline Job Alternatives & .12 & .19 & .03 \\
\hline
\end{tabular}

\section{Discussion}

Consistent with previous research concerning attitudinal measures predicting intent to leave and voluntary turnover, Hypothesis 1 , which stated that high levels of job satisfaction would be related to lower intent to leave, was significant. The results also, 
however, showed some interesting discrepancies with previous research on turnover. High levels of organizational commitment have repeatedly been shown to predict low levels of intent to leave, yet in our sample, hypothesis 2 was not significant. Following previous research on "ease of movement" factors, hypothesis 3 predicted that perceived job alternatives would be related to higher intent to leave. Surprisingly, the data did not support this hypothesis. The perception of job alternatives was not related to higher levels of intent to leave. Hypothesis 4, in the same vein, predicted that job search behaviors would be related to higher intent to leave. According to prior research and theory on turnover, "There is near unanimity of opinion that the most immediate precursor (conceptually) and the best predictor of turnover behavior (empirically) is the intention to leave/quit/resign (e.g., Dougherty, Bluedorn, \& Keon, 1985; Mobley, Horner, \& Hollingsworth, 1978; Steel \& Ovalle, 1984; Steers \& Mowday, 1981)" (p. 270; Kopelman, Rovenpor, \& Millsap, 1992). The data supported hypothesis 4, suggesting that the act of preparing to leave was predictive of intent. This was consistent with prior findings, though it is interesting to note that the perception that an actual job existed for the individual was not predictive, yet the act of searching was. In directly testing the job embeddedness construct, we suggested (H5) that job embeddedness would be negatively related to intent to leave over and above that accounted for by job satisfaction and organizational commitment. In this sample, however, we found that the single largest predictor of turnover was satisfaction. In hypothesis 6 we suggested that job embeddedness would be negatively related to intent to leave over and above that accounted for by the attitudinal measures of job search and perceived job alternatives. The data supported this hypothesis, which, along with hypothesis 7 , indicated that the perception of job alternatives would predict intention to leave over and above that accounted for by job satisfaction and organizational commitment. These data supported the strength of attitudinal measures above those of labor market, "ease of movement," variables.

\section{Limitations and Conclusion}

The findings were somewhat surprising considering the robust nature of job embeddedness in U.S. samples. It may be that the economic development of Albania is motivating a volatile employment situation. As new businesses move in, and as migrant workers with substantial human capital enter the major cities, this volatility will most likely continue. The economy of Albania is improving, with a 5.5\% annual growth in GDP between the years of 2003 and 2006, and inflation has remained low, at an average of $2.5 \%$ in 2006 (U.S. Department of State, 2007). According to the European Union: The services sector is one of the most dynamic and accounts for a large part of the economy, $57.9 \%$ of GDP, while agriculture accounts for $23.3 \%$ and industry for $18.8 \%$. The growth of the services and industrial sectors has increased while growth has remained modest in the agricultural sector. The income per capita in Albania, measured in purchasing power, amounted to around $18 \%$ of the EU-27 average (Albania Country Guide, August 2006).

With the second largest sector of Albania's economy engaged in services, and the majority of development having occurred in Tirana (U.S. Department of State, 2007), 
those who are in banking have arguably the most opportunity to change jobs within the banking industry. Interestingly, the links component of job embeddedness was not useable with this sample. Our interpretation of this is that these individuals, as migrant workers, have little in the way of linkages either on or off the job, though had the links been assessed within the industry, we may have found more evidence for being linked to the industry rather than to any one organization. This would be expected to continue until the mass migration of workers begins to slow and the population stabilizes.

One of the most surprising findings was the lack of influence from organizational commitment. The individuals studied appeared to neither plan to nor expect to continue in their current organizations. One possible explanation for this finding is the influence of the industry on the individual level of commitment. Because the banks included in our survey are viewed as large, attractive places of employment, these employees may have viewed their human capital as providing them with the means necessary to move from one bank to another, increasing their ease of movement. Thus, we expected them to be more committed to their industry or profession than to any individual bank. This would go a long way to explain the differential effects of job satisfaction and organizational commitment. If the employees perceived relatively high levels of ease of movement within the industry, they might be more driven by satisfaction with the job itself regardless of the company in which the job was located.

The second most surprising finding was the significance of job search behaviors on intent to leave while perceptions of job availability were not significant predictors of intent to leave. Again, the perception of having human capital that can get one a job in the banking industry might be the reason for this finding. These individuals may view themselves as highly competitive and capable of getting the bank to create a job for them rather than have to compete for an available position.

Our sample size was relatively small, yet as the response rate was high, we feel our findings could generalize to the banking employee population and the general Albanian population. Our surveys came from one source, the individual employee. We were not able to gain information on actual turnover from the management in the short time frame of this project. However, according to Mobley, Griffeth, Hand and Meglino, (1979), the intention to leave is the direct precursor to actual turnover, so we feel somewhat confident in our measure.

Overall, this research provided cross-cultural support for job satisfaction, and raised issues about how generalizable the job embeddedness construct is. Perhaps job embeddedness is most predictive in areas where the economy is relatively stable and unemployment is low. Managers can take this information as evidence of the importance of job satisfaction. Based on this evidence, managers can develop interventions to help raise the levels of job satisfaction of their workers and reduce turnover. Many participants in this survey were engaging in job search behaviors. Should a manager wish to curb the loss of good employees, he or she could use the opportunity to be the employer sought out. Considering the type of job search behaviors, participants most often $58 \%$ looked to friends and family for job information. Using these types of informal networks to promote the organization as the employer of 
choice could greatly benefit the organization. Future research should focus on expanding these possibilities and work to develop the turnover literature to uncover components that are universal in their predictive ability such as the job satisfaction construct.

\section{References}

Blau, G. (1993). Further exploring the relationship between job search and voluntary individual turnover. Personnel Psychology, 46, 313-330.

Bluedorn, A. (1982). A unified model of turnover from organizations. Human Relations, 35, 135-153.

Carsten, J. M., \& Spector, P. E. (1987). Unemployment, job satisfaction and employee turnover: A meta-analytic test of the Muchinsky model. Journal of Applied Psychology, 72, 374-381.

Curry, J. P., Wakefield, D. S., Price, J. L., \& Mueller, C. W. (1986). On the causal ordering of job satisfaction and organizational commitment. Academy of Management Journal, 29, 847-858.

Dougherty, T. W., Bluedorn, A. C., Keon, T. L. (1985). Precursors of employee turnover: A multiple-sample causal analysis. Journal of Occupational Behavior, 6, 259-271.

EUB2 (2006). Albania country guide. European Union Business. Retrieved on February 1, 2008 from http://www.eubusiness.com/Albania/albania-country-guide.

Farrell, D., Rusbult, C. E., (1981). Exchange variables as predictors of job satisfaction, job commitment, and turnover. The impact of rewards, costs, alternatives, and investments. Organizational Behavior and Human Performance, 28, 78-95.

Gerhart, B. (1990). Voluntary turnover and alternative job opportunities. Journal of Applied Psychology, 75, 467-476.

Griffeth, R. W., Hom, P. W., \& Gaertner, S. (2000). A meta-analysis of antecedents and correlates of employee turnover: Update, moderator tests, and research implications for the next millennium. Journal of Management, 26, 463-488.

Hom, P. W., \& Griffeth, R. W. (1991). Structural modeling test of a turnover theory: Cross sectional and longitudinal analyses. Journal of Applied Psychology, 76, 350-366.

Hom, P. W., Griffeth, R. W., \& Sellaro, C. L. (1984). The validity of Mobley's (1977) model of employee turnover. Organizational Behavior and Human Performance, $34,141-174$. 
Hulin, C. L., Roznowski, M., \& Hachiya, D. (1985). Alternative opportunities and withdrawal decisions: Empirical and theoretical discrepancies and an integration. Psychological Bulletin, 97, 233-250.

Institute of Statistics of Albania (2004). General results of structural survey of economics enterprises for 2004.

Kopelman, R. E., Rovenpor, J. L., \& Millsap, R. E. (1992). Rationale and construct validity evidence for the Job Search Behavior Index: Because intentions (and New Year's resolutions) often come to naught. Journal of Vocational Behavior, 40, 269-287.

Lee, T. W., \& Mitchell, T. R. (1994). An alternative approach: The unfolding model of voluntary employee turnover. Academy of Management Review, 19, 51-89.

Lee, T. W., Mitchell, T. R., Sablynski, C. J., Burton, J. P., \& Holtom, B. C. (2004). The effects of job embeddedness on organizational citizenship, job performance, volitional absences, and voluntary turnover. Academy of Management Journal, $47,711-722$.

March, J. G., \& Simon, H. A. (1958). Organizations. New York: John Wiley.

Mathieu, J. E., \& Zajac, D. M. (1990). A review and meta-analysis of the antecedents, correlates, and consequences of organizational commitment. Psychological Bulletin, 108, 171-194.

Meyer, J. P., \& Allen, N. J. (1988). Links between work experiences and organizational commitment during the first year of employment: A longitudinal analysis. Journal of Occupational Psychology, 61, 195-209.

Mitchell, T. R., Holtom, B. C., Lee, T. W., Sablynski, C. J., \& Erez, M. (2001). Why people stay: Using job embeddedness to predict voluntary turnover. Academy of Management Journal, 44, 1102-1121.

Mobley, W. H. (1977). Intermediate linkages in relationship between job satisfaction and employee turnover. Journal of Applied Psychology, 62, 237-240.

Mobley, W. H., Griffeth, R. W., Hand, H. H., \& Meglino, B. M. (1979). Review and conceptual analysis of the employee turnover process. Psychological Bulletin, $86,493-522$.

Mobley, W. H., Horner, S. O., \& Hollingsworth, A. T. (1978). Evaluation of precursors of hospital employee turnover. Journal of Applied Psychology, 63, 408-414.

Porter, L. W., \& Steers, R. M. (1973). Organizational, work, and personal factors in employee turnover and absenteeism. Psychological Bulletin, 80, 151-176. 
Price, J. L. (1977). The study of turnover. lowa State University Press: Ames, IA.

Sheridan, J. E., \& Abelson, M. A. (1983). Cusp catastrophe model of employee turnover. Academy of Management Journal, 26, 418-436.

Spector, P. E. (1997). Job satisfaction. Thousand Oaks, CA: Sage Publications, Inc.

Steel, R. P., \& Griffeth, R. W. (1989). The elusive relationship between perceived employment-opportunity and turnover behavior: A methodological or conceptual artifact. Journal of Applied Psychology, 74, 846-854.

Steel, R. P., \& Ovalle, N. K. (1984). A review and meta-analysis of research on the relationship between behavioral intentions and employee turnover. Journal of Applied Psychology, 69, 673-686.

Steers, R. M., \& Mowday, R. T. (1981). Employee turnover and postdecision accommodation processes. In L. L. Cummings \& B. M. Staw (Eds.) Research in Organizational Behavior (235-281). JAI Press: Greenwich, CT.

U.S. Department of State. (2007). Bureau of European and Eurasian Affairs background note: Albania. Retrieved on February 1, 2008 from http://www.state.gov/r/pa/ei/bgn/3235.htm.

World Bank. (2008). Data and statistics. Retrieved September 5, 2008 from http://web.worldbank.org/WBSITE/EXTERNAL/COUNTRIES/ECAEXT/ALBANIA EXTN/0, menuPK:301437 pagePK:141132 piPK:141109 theSitePK:301412,00. html?gclid=CJWVyqqPxZUCFQuwGgodLH6UiA 